\title{
Altering the coenzyme preference of xylose reductase to favor utilization of NADH enhances ethanol yield from xylose in a metabolically engineered strain of Saccharomyces cerevisiae Barbara Petschacher and Bernd Nidetzky*
}

\author{
Address: Institute of Biotechnology and Biochemical Engineering, Graz University of Technology, Petersgasse 12/I, A-8010 Graz, Austria \\ Email: Barbara Petschacher - barbara.petschacher@gmx.at; Bernd Nidetzky* - bernd.nidetzky@tugraz.at \\ * Corresponding author
}

Published: 17 March 2008

Microbial Cell Factories 2008, 7:9 doi:10.1 186/1475-2859-7-9
Received: 22 January 2008

Accepted: 17 March 2008

This article is available from: http://www.microbialcellfactories.com/content/7///9

(C) 2008 Petschacher and Nidetzky; licensee BioMed Central Ltd.

This is an Open Access article distributed under the terms of the Creative Commons Attribution License (http://creativecommons.org/licenses/by/2.0), which permits unrestricted use, distribution, and reproduction in any medium, provided the original work is properly cited.

\begin{abstract}
Background: Metabolic engineering of Saccharomyces cerevisiae for xylose fermentation into fuel ethanol has oftentimes relied on insertion of a heterologous pathway that consists of xylose reductase $(X R)$ and xylitol dehydrogenase $(X D H)$ and brings about isomerization of xylose into xylulose via xylitol. Incomplete recycling of redox cosubstrates in the catalytic steps of the $\mathrm{NADPH}$-preferring $\mathrm{XR}$ and the NAD+-dependent $\mathrm{XDH}$ results in formation of xylitol by-product and hence in lowering of the overall yield of ethanol on xylose. Structure-guided site-directed mutagenesis was previously employed to change the coenzyme preference of Candida tenuis XR about 170-fold from NADPH in the wild-type to NADH in a Lys ${ }^{274} \rightarrow$ Arg Asn ${ }^{276} \rightarrow$ Asp double mutant which in spite of the structural modifications introduced had retained the original catalytic efficiency for reduction of xylose by NADH. This work was carried out to assess physiological consequences in xylose-fermenting $S$. cerevisiae resulting from a well defined alteration of $X R$ cosubstrate specificity.

Results: An isogenic pair of yeast strains was derived from S. cerevisiae Cen.PK II3-7D through chromosomal integration of a three-gene cassette that carried a single copy for $C$. tenuis $X R$ in wildtype or double mutant form, $\mathrm{XDH}$ from Galactocandida mastotermitis, and the endogenous xylulose kinase (XK). Overexpression of each gene was under control of the constitutive TDH3 promoter. Measurement of intracellular levels of XR, XDH, and XK activities confirmed the expected phenotypes. The strain harboring the $X R$ double mutant showed $42 \%$ enhanced ethanol yield $(0.34$ $\mathrm{g} / \mathrm{g}$ ) compared to the reference strain harboring wild-type $\mathrm{XR}$ during anaerobic bioreactor conversions of xylose $(20 \mathrm{~g} / \mathrm{L})$. Likewise, the yields of xylitol $(0.19 \mathrm{~g} / \mathrm{g})$ and glycerol $(0.02 \mathrm{~g} / \mathrm{g})$ were decreased $52 \%$ and $57 \%$ respectively in the XR mutant strain. The xylose uptake rate per gram of cell dry weight was identical $\left(0.07 \pm 0.02 \mathrm{~h}^{-1}\right)$ in both strains.
\end{abstract}

Conclusion: Integration of enzyme and strain engineering to enhance utilization of NADH in the $X R$-catalyzed conversion of xylose results in notably improved fermentation capabilities of recombinant S. cerevisiae. 


\section{Background}

Rising oil prices and a growing awareness of a possible climate change caused by greenhouse gas emission have recently led to rekindled interest in bioethanol as a $\mathrm{CO}_{2}^{-}$ neutral liquid fuel. Lignocellulose will be the prime choice of feedstock for the production of bioethanol if major technical problems in its conversion can be overcome $[1,2]$. One notable difficulty has been in the development of robust microbial strains capable of fermenting efficiently all types of sugars present in the cellulose and hemicellulose fractions of the raw material [3-6]. While Saccharomyces cerevisiae is a top candidate to be used in the fermentation of D-glucose and the hemicellulose-derived hexoses D-galactose and D-mannose, the organism in its wild-type form cannot utilize the pentoses D-xylose and L-arabinose $[3,4,6-11]$ which constitute $\geq 80 \%$ of the total sugar contained in typical hemicellulose hydrolyzates [12]. The particular deficiency of $S$. cerevisiae is caused by an insufficient expression of pathways which in other yeasts deliver either of the two sugars as D-xylulose 5phosphate into the central metabolism (Figure 1).

Initial efforts of strain engineering in S. cerevisiae targeted expansion of the substrate spectrum towards D-xylose and involved heterologous expression of Pichia stipitis genes encoding xylose reductase (XR) and xylitol dehydrogenase $(\mathrm{XDH})$ [13-15]. Overexpression of an endogenous xylulose kinase (XK) gene was used to eliminate a putative kinetic bottleneck in the phosphorylation of D-xylulose

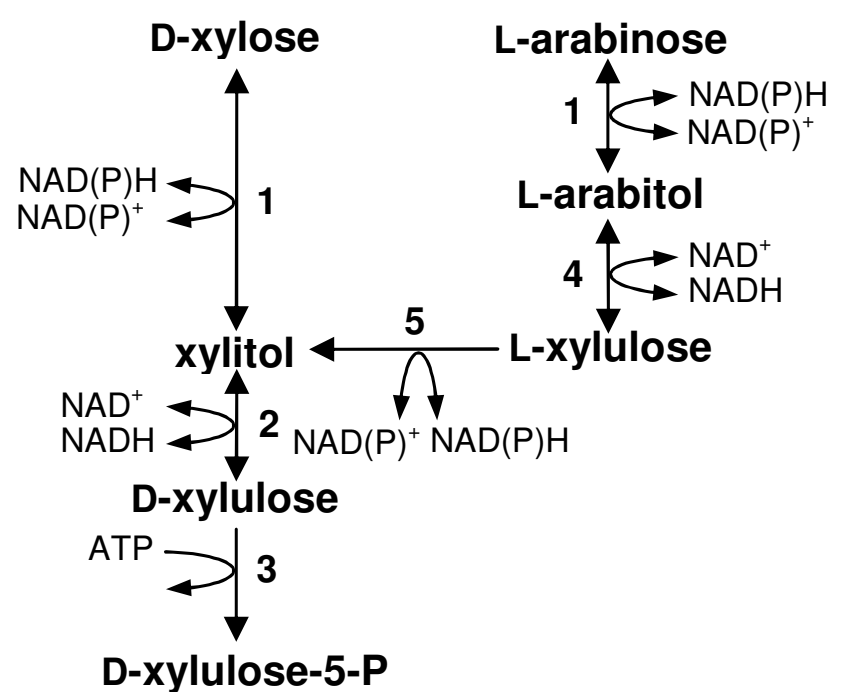

Figure I

Pathways for utilization of D-xylose and L-arabinose in fungi. I, aldose reductase (EC I.I.I.2I); 2, xylitol dehydrogenase (EC I.I.I.9); 3, xylulose kinase (EC 2.7.I.I7); 4, Larabinitol 4-dehydrogenase (EC I.I.I.I2); 5, L-xylulose reductase (EC I.I.I.IO).
[16-18]. Ethanol yields obtained with this first generation of xylose-fermenting strains were far below the theoretical maximum of $0.51 \mathrm{~g} / \mathrm{g}$ xylose, because a large part of the xylose consumed was excreted as xylitol. This was attributed to an imbalanced coenzyme utilization in the steps catalyzed by a dual specific, NADPH-preferring XR and a strictly $\mathrm{NAD}^{+-}$-dependent XDH [reviewed in $\left.[1-6,10]\right]$, a fundamental problem recognized before in seminal studies of xylose utilization by yeasts [13,19-21]. Strategies to decrease xylitol formation have included re-oxidation of excess NADH by external electron acceptors [22], manipulations of the yeast central metabolism at various $\operatorname{NADP}(\mathrm{H})$ or $\mathrm{NAD}(\mathrm{H})$-dependent steps outside the xylose pathway [23-27] and more recently, engineering of the coenzyme specificity of XR $[28,29]$ or XDH [30-32]. The conceptually most compelling approach is replacement of $\mathrm{XR}$ and XDH by a xylose isomerase (XI), so that xylose can be directly transformed into xylulose [33,34]. However, identification of a candidate XI for high-level functional expression in S. cerevisiae proved difficult [35]. Pronk and coworkers isolated a novel XI from a fungal source (Pyromyces sp. ATCC 76762) [32] and succeeded in constructing a xylose-fermenting yeast strain based on this enzyme [36-38]. High ethanol yields of $0.42 \mathrm{~g} / \mathrm{g}$ and almost no xylitol formation were observed in batch fermentations on $20 \mathrm{~g} / \mathrm{L}$ xylose [36]. A recent comparison of xylose-fermenting yeast strains carrying the $P$. stipitis XR-XDH pathway or the Pyromyces XI pathway revealed that the XR$\mathrm{XDH}$ strategy resulted in a 2.6-fold faster ethanol production rate although the overall ethanol yield $(0.33 \mathrm{~g} / \mathrm{g})$ was significantly lower than in the strain carrying XI $(0.43 \mathrm{~g} / \mathrm{g})$ [39]. An engineered XR-XDH pathway in which formation of excess NADH is reduced while the fluxional efficiency of the wild-type pathway is retained could therefore be the key to the construction of new xylose-fermenting strains that combine both good yield and productivity.

We have recently employed structure-guided site-directed mutagenesis to change the coenzyme preference of Candida tenuis XR from NADPH (33-fold) in the wild-type enzyme to NADH (5-fold) in a Lys ${ }^{274} \rightarrow$ Arg Asn ${ }^{276} \rightarrow$ Asp double mutant (K274R-N276D) [40]. According to its kinetic parameters, K274R-N276D is expected to fully substitute for the wild-type enzyme during NADHdependent reduction of xylose in a recombinant strain of $S$. cerevisiae. Results of in vitro assays suggest that the double mutant will probably show indiscriminate usage of NADH and NADPH under physiological reaction conditions [41]. This work was carried out to verify the predicted in vivo function of K274R-N276D and analyze consequences in xylose-fermenting $S$. cerevisiae that result from a well defined change in XR coenzyme specificity. 


\section{Results \\ Development of stable xylose-fermenting strains of S. cerevisiae expressing $C$. tenuis $X R$ in wild-type or K274R- N276D double mutant form}

Two isogenic yeast strains were derived from the laboratory strain S. cerevisiae CEN.PK 113-7D. Single copies for the genes encoding CtXR in wild-type (strain BP000) or K274R-N276D double mutant form (strain BP10001) and XDH from Galactocandida mastotermitis (GmXDH) were inserted in the URA3-locus of the yeast genome together with an extra copy of the endogenous XK gene (Table 1). Both strains grew aerobically on xylose with nearly identical specific growth rates of about $0.07 \mathrm{~h}^{-1}$. Their specific rates of growth and substrate consumption during aerobic and anaerobic conversion of glucose were also very similar. As expected, the reference strain $S$. cerevisiae CEN.PK 113-7D was unable to utilize xylose for aerobic growth or as fermentation substrate (data not shown). Table 2 summarizes specific activities of $\mathrm{XR}$, $\mathrm{XDH}$, and XK in cell extracts of BP000 and BP10001 cultivated aerobically in mineral medium containing $20 \mathrm{~g} / \mathrm{L}$ of each glucose and xylose. However, xylose could be omitted from the medium without any effect on the specific activity of each of the three enzymes. For reasons we do not understand, BP10001 showed a significantly, about 1.8-fold higher level of XR activity than BP000, irrespective of various growth conditions and times of cell harvest used. The specific activity of XK was also higher $(\approx 40 \%)$ in BP10001 than in BP000. The levels of XDH activity were comparable in the two strains. Cell extracts prepared by using Y-PER contained 1.4-fold higher specific XR activity than others obtained by disrupting exactly comparable cell material in a French Press. While the result is explicable on account of XR activity enhancement by the detergents present in Y-PER (data not shown; see ref. [42] for the effect of non-ionic detergents on activity and stability of $(\mathrm{XXR})$, it also provides a note of caution regarding the comparison of enzyme activities that are based on different methods of yeast cell disruption.

Figure 2 compares XR activities of BP000 and BP10001 recorded at three concentrations of NADH and NADPH. The relative decrease in enzymatic rate in response to lowering the level of NADH from $350 \mu \mathrm{M}$ to $7 \mu \mathrm{M}$ was similar in the two strains. By contrast, the drop in activity caused by the same change in the concentration of NADPH was much more significant in BP10001 than in BP000. These results are in excellent agreement with expectations from the $K_{\mathrm{m}}$ values of purified wild-type (NADH: $38 \mu \mathrm{M}$; NADPH: $3 \mu \mathrm{M}$ ) and K274R-N276D (NADH: $41 \mu \mathrm{M}$; NADPH: $128 \mu \mathrm{M}$ ) [40]. They also serve to verify functional expression of the double mutant in BP10001.

\section{Oxygen-limited conversion of xylose in shake-flask cultures}

Batch conversions of xylose by glucose-grown resting cells of BP000 and BP10001 were carried out under oxygenlimited reaction conditions $\left(\left[\mathrm{O}_{2}\right] \leq 20 \mu \mathrm{M}\right)$ in shake flasks using a mineral medium that contained $20 \mathrm{~g} / \mathrm{L}$ sugar. Typical fermentation time courses are shown in Figure 3 and parameters derived from their analysis are summarized in Table 3. No biomass was formed under these conditions. In a carbon balance calculated from the data in Figure 3 whereby $\mathrm{CO}_{2}$ was inferred from the ethanol and acetate values, only $\leq 7 \%$ of the carbon from xylose remained unaccounted for. In comparison with the reference strain BP000, the XR double mutant strain BP10001 showed $40 \%$ enhanced ethanol yield. Its production of xylitol and glycerol was decreased by 53\% and 30\%, respectively. The yield of acetate was generally low in both strains, however, enhanced by about 50\% in BP10001.

\begin{abstract}
Anaerobic conversions of xylose in bioreactor experiments To verify the results of shake flask experiments under well controlled fermentation conditions where in particular the concentration of dissolved oxygen was monitored continuously, we compared anaerobic conversions of xylose $(20 \mathrm{~g} / \mathrm{L})$ by BP10001 and BP000 carried out in a Braun Biostat bioreactor. Results are summarized in Figure 4 and Table 3. For both strains, the physiological parameters measured in the bioreactor were in good agreement with the ones obtained in shake flask. The glycerol yield was an exception as bioreactor experiments gave significantly lower values in this case. Likewise, the acetate yield for strain BP10001 was lower in bioreactor compared to shake flask cultivations and identical to the corresponding acetate yield for the control strain $(0.019 \mathrm{~g} / \mathrm{g})$. Therefore, positive effects in the XR double mutant strain on xylose fermentation in shake flask could be scaled up fully to the laboratory bioreactor.
\end{abstract}

Table I: Relevant genotypes and phenotypes of strains BP000 and BP I000 I

\begin{tabular}{lll}
\hline Strain & Relevant genotype & Phenotype \\
\hline BP000 & $\begin{array}{l}\text { CEN.PK I I3-5D ura3::(GPDP-XKSI-CYCIt, GPDP-CtXRWt-CYCIt, } \\
\text { GPDP-GmXDH-CYCIt) }\end{array}$ & Produces CtXR wild type + GmXDH, overexpresses XKSI \\
BPI000I & $\begin{array}{l}\text { CEN.PK II3-5D ura3::(GPDP-XKSI-CYCIt, GPDP-CtXRDm-CYCIt, } \\
\text { GPDP-GmXDH-CYCIt) }\end{array}$ & $\begin{array}{l}\text { Produces CtXR K274RN276D double mutant + GmXDH, } \\
\text { overexpresses XKSI }\end{array}$ \\
\hline
\end{tabular}

GPDP and CYCIt stand for the S. cerevisiae TDH3 promoter and CYCI terminator, respectively. 
Table 2: XR, XDH and XK activities in crude cell extracts of BP000 and BPIO00I. Cells were grown aerobically on a mixed sugar substrate containing $20 \mathrm{~g} / \mathrm{L}$ of each glucose and xylose and were then disrupted with Y-Per.

\begin{tabular}{|c|c|c|c|c|}
\hline \multirow{2}{*}{$\begin{array}{l}\text { Strain } \\
\text { BP000 }\end{array}$} & \multicolumn{2}{|c|}{$X R$ activity $U / \mathrm{mg}^{\mathrm{a}}$} & \multirow{2}{*}{$\begin{array}{c}\text { XDH activity U/mg } \\
\text { I.I } \pm 0.1\end{array}$} & \multirow{2}{*}{$\begin{array}{c}\text { XK activity } \mathrm{U} / \mathrm{mg} \\
\mathrm{I} .7 \pm 0.2\end{array}$} \\
\hline & $\mathrm{NADH}$ & $0.15 \pm 0.0 \mathrm{I}^{\mathrm{b}}$ & & \\
\hline & NADPH & $0.18 \pm 0.01$ & & \\
\hline \multirow[t]{2}{*}{ BPI000I } & $\mathrm{NADH}$ & $0.26 \pm 0.01$ & $1.3 \pm 0.1$ & $2.4 \pm 0.1$ \\
\hline & NADPH & $0.33 \pm 0.01$ & & \\
\hline Cen.PK II3-7D & NADH & $\begin{array}{c}\text { n.d.c } \\
\text { c }\end{array}$ & n.d. & $0.14 \pm 0.04$ \\
\hline
\end{tabular}

a Activities measured using a coenzyme concentration of $350 \mu \mathrm{M}$ and a xylose concentration of $700 \mathrm{mM}$

b Mean values \pm S.D. from three independent experiments including cultivation and disruption of cells and measurement of protein and activity

c n.d. not detectable.

\section{Discussion}

Protein engineering to improve coenzyme recycling in the metabolic steps catalyzed by $X R$ and XDH

Biochemical constraints dictate that anaerobic conversion of xylose into ethanol is possible only when XR and XDH have matching coenzyme specificities [19,21,43]. The xylose pathway from Pichia stipitis which has served as point of departure for the construction of numerous xylose-fermenting strains of $S$. cerevisiae $[4,6]$ does not fulfill this requirement well. Its $\mathrm{XDH}$ is strictly specific for $\mathrm{NAD}^{+}$[44] while the XR strongly prefers NADPH over

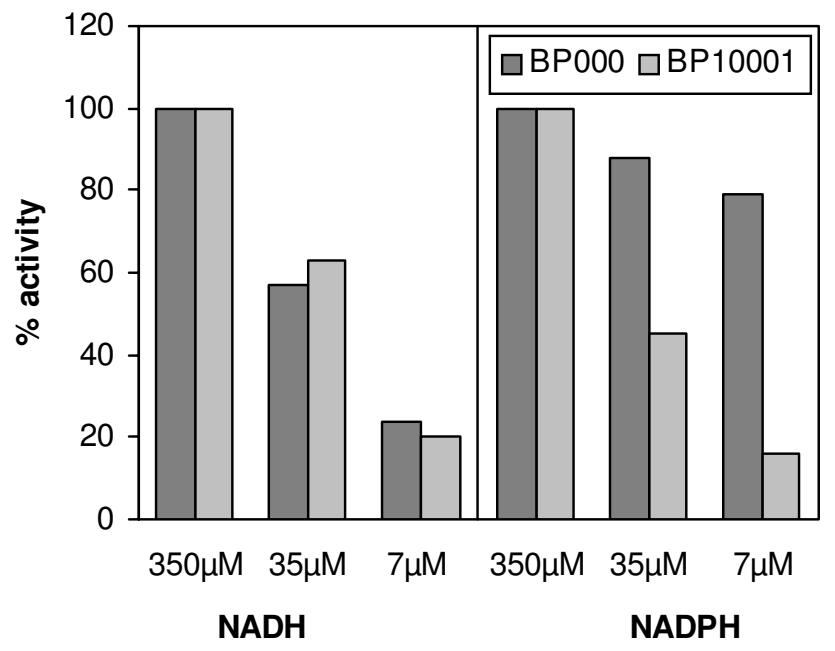

Figure 2

Comparison of XR activities of BP000 and BPI000 I at different cofactor concentrations. Cells were grown aerobically on $20 \mathrm{~g} / \mathrm{L}$ glucose and $20 \mathrm{~g} / \mathrm{L}$ xylose and disrupted with Y-Per reagent. One hundred \% specific activity of strain BP000 corresponds to values of $0.15 \mathrm{U} / \mathrm{mg}$ with $\mathrm{NADH}$ and $0.18 \mathrm{U} / \mathrm{mg}$ with NADPH. In strain BPI000I, the specific activities are $0.26 \mathrm{U} / \mathrm{mg}$ with $\mathrm{NADH}$ and $0.33 \mathrm{U} / \mathrm{mg}$ with NADPH.
$\mathrm{NADH}[45,46]$. Using known natural enzymes, the assembly of a chimeric pathway in which XR and XDH show exactly comparable utilization of $\mathrm{NADP}(\mathrm{H})$ and $\mathrm{NAD}(\mathrm{H})$ appears to be currently out of reach.

Protein engineering has therefore been pursued to make the coenzyme specificity of XR or XDH better compatible with that of the corresponding partner enzyme of the xylose pathway. Following the early studies by Metzger and Hollenberg [47], Makino and coworkers succeeded in creating a NADP $(\mathrm{H})$-dependent version of $P$. stipitis $\mathrm{XDH}$ through rational design [32]. A notable feature of the best improved multiple mutant of $\mathrm{XDH}$ was a catalytic efficiency for the $\mathrm{NADP}^{+-}$-dependent reaction that exceeded about 3.8-fold the corresponding efficiency of the wildtype using $\mathrm{NAD}^{+}$. While $\mathrm{XDH}$ from yeast and fungal sources is typically a $\mathrm{Zn}^{2+}$-dependent enzyme evolutionary related to medium-chain dehydrogenases/reductases $[48,49]$, bacterial polyol dehydrogenases possessing activity with xylitol do not use an active-site metal in catalysis and are found with the short-chain dehydrogenase/ reductase superfamily of proteins [50]. Ehrensberger and Wilson [51] determined a $1.9 \AA$ crystal structure of XDH from Gluconobacter oxidans based on which they were able to convert the $\mathrm{NAD}^{+}$-dependent wild-type enzyme into a strictly $\mathrm{NADP}^{+}$-specific variant that had retained about $14 \%$ of the original catalytic efficiency for oxidation of xylitol.

Successful creation of a highly active XR mutant featuring a substantially lower preference for NADPH than the wild-type enzyme has strongly benefited from crystal structures of the enzyme from $C$. tenuis bound with NADP(H) [52] and NAD $(H)$ [53]. Some of the mutations found to be useful in CtXR [40] were later also introduced at homologous positions of the amino acid sequence of XR from $P$. stipitis $[28,29,54]$ (see later). Selection of the K274R-N276D doubly mutated CtXR for the in vivo experiments reported herein was based on a detailed steady- 
Table 3: Comparison of xylose fermentation by the recombinant S. cerevisiae strains BP000 and BPI000I

\begin{tabular}{|c|c|c|c|c|}
\hline & \multicolumn{2}{|c|}{ BP000 } & \multicolumn{2}{|c|}{ BPIO00I } \\
\hline & Shake flask (oxygen limited) & Bioreactor (anaerobic) & Shake flask (oxygen limited) & Bioreactor (anaerobic) \\
\hline$q_{\text {xylose }}{ }^{a}$ & 0.07 & 0.06 & 0.07 & $0.08^{d}$ \\
\hline$Y_{\text {ethanol }}$ & 0.24 & 0.24 & 0.34 & 0.34 \\
\hline$Y_{\text {xylitol }}$ & 0.35 & 0.39 & 0.17 & 0.19 \\
\hline$Y_{\text {glycerol }}^{\text {xymor }}$ & 0.091 & 0.048 & 0.063 & 0.021 \\
\hline$Y_{\text {acetate }}$ & 0.019 & 0.019 & 0.031 & 0.020 \\
\hline C-recovery & $93 \% c$ & $101 \%$ & $94 \% c$ & $96 \%$ \\
\hline
\end{tabular}

a Xylose uptake rates $(q)$ are given in $g / g C D W / h$

b Yields $(Y)$ are given in $g / g$ xylose.

c For the calculation of the carbon balance, it was assumed that one mole of $\mathrm{CO}_{2}$ was formed per mol of ethanol or acetate

The given values were obtained by analyzing samples taken in the range $45-60 \%$ xylose consumption. Shake flask experiments were done in triplicates, bioreactor experiments in duplicate. Mean values are shown. Their relative S.D. was $<5 \%$ with the exception of values of $q_{\mathrm{xy}}$ lose and

$Y_{\text {acetate }}$ from shake flasks experiments whose S.D. was $\leq 14 \% .{ }^{d}$ he S.D. for this value was about $30 \%$.

state kinetic characterization of a series of single and multiple-site variants of $C t \mathrm{XR}[40]$ and included analysis of mixed coenzyme utilization in the presence of physiological concentrations of NADPH and NADH [41]. The double mutant eliminates the 33-fold preference of the wildtype for reaction with NADPH; however, it is clearly not a perfectly NADH-dependent enzyme. With the desired application for xylose fermentation in mind, it was important to also consider the possible effect of the mutated XR on the fluxional efficiency of the xylose pathway. The K274R-N276D double mutant was expected from its kinetic parameters to substitute the wild-type enzyme in

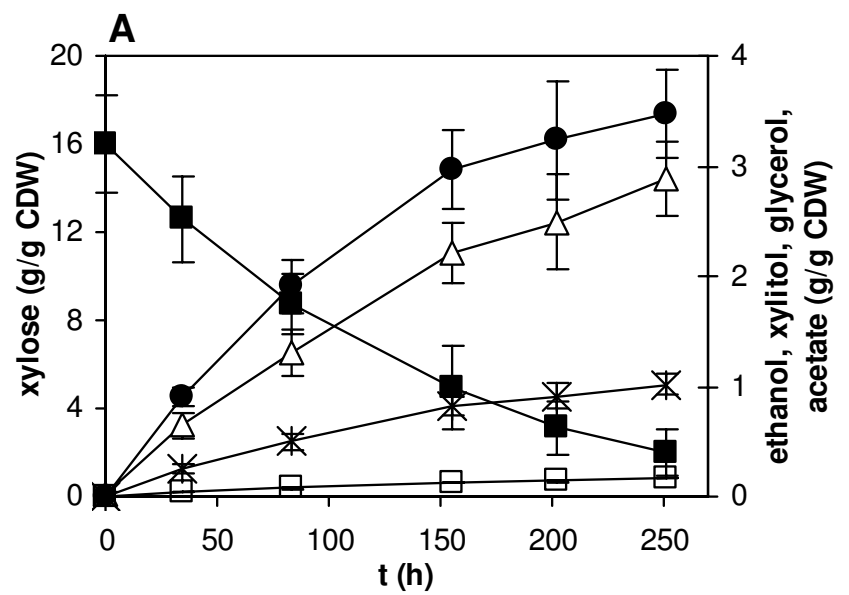

the $\mathrm{NAD}(\mathrm{H})$-dependent conversion of xylose without introducing an extra kinetic bottleneck.

\section{Metabolic consequences of altering the coenzyme preference of $X R$ in a xylose-fermenting strain of $S$. cerevisiae}

The discussion will focus on physiological effects observed in stable xylose-fermenting strains of $S$. cerevisiae where the relevant genes were integrated into the yeast genome. Note, however, that preliminary reports have been published in which xylose fermentation by yeast strains expressing mutated $P$. stipitis XR or $\mathrm{XDH}$ from multi-copy plasmid vectors was investigated. They sup-

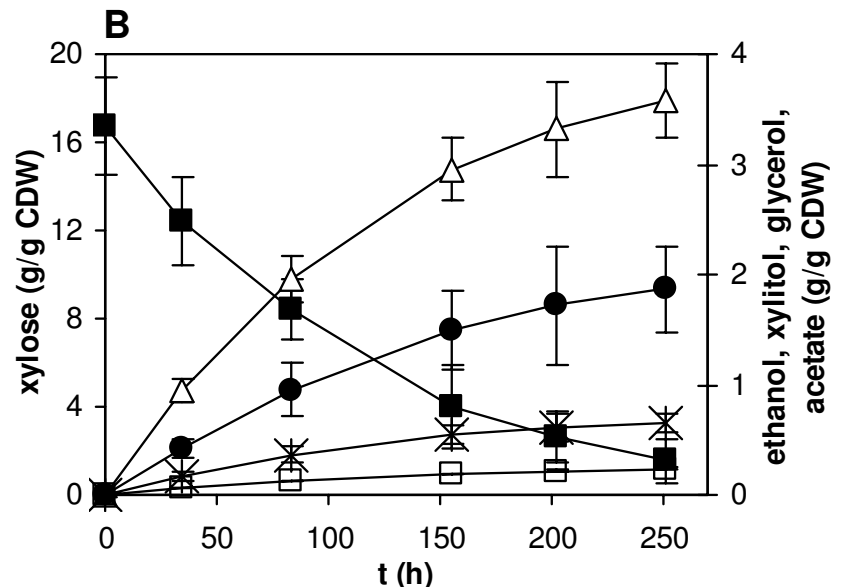

Figure 3

Xylose utilization and product formation during oxygen-limited shake flask cultivation of BP000 (panel A) and BPIO00I (panel B). Xylose (full squares), ethanol (triangles), xylitol (circles), glycerol (stars) and acetate (empty squares) were analyzed by HPLC. The biomass concentration was constant at I.4 $\pm 0 . \mathrm{I} \mathrm{g} / \mathrm{L}$ for BP000 and I.5 $\pm 0 . \mathrm{I} \mathrm{g} / \mathrm{L}$ for BPI000I. Error bars show the S.D. of triplicate fermentation experiments. 

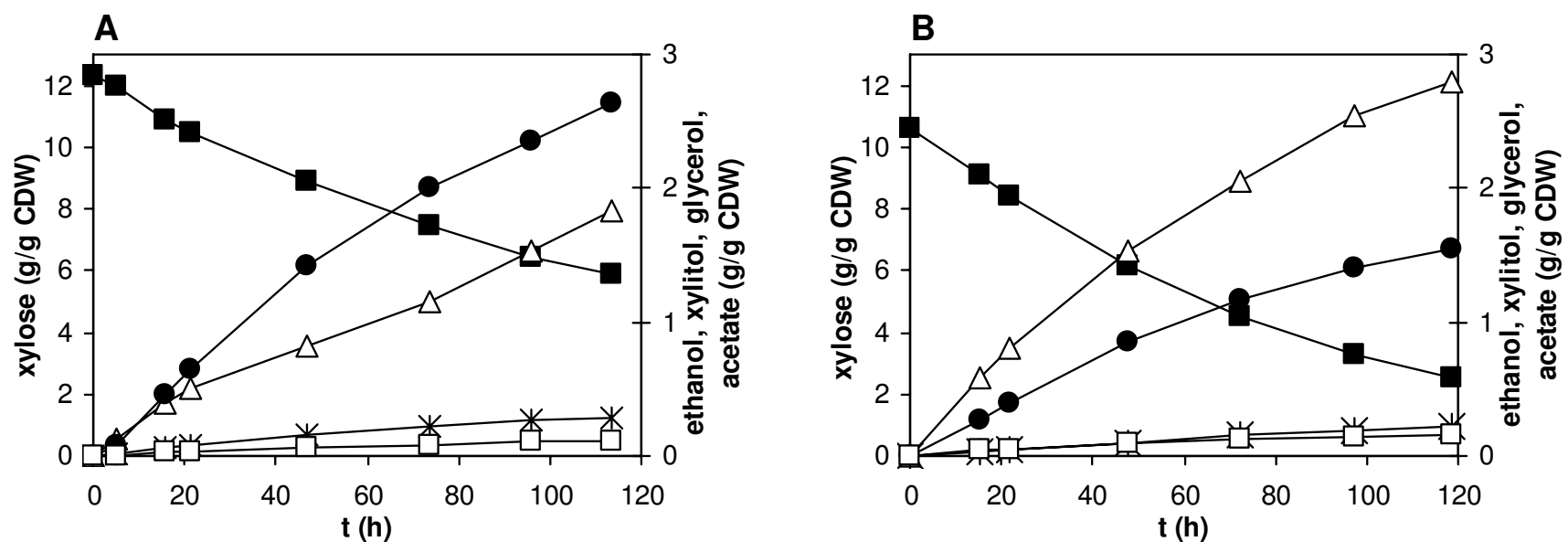

\section{Figure 4}

Xylose utilization and product formation during anaerobic bioreactor cultivation of BP000 (panel A) and

BPIO00I (panel B). Xylose (full squares), ethanol (triangles), xylitol (circles), glycerol (stars) and acetate (empty squares) were analyzed by HPLC. The biomass concentration was constant at I.6 $\pm 0.1 \mathrm{~g} / \mathrm{L}$ for BP000 and I.8 $\pm 0 . \mathrm{I} \mathrm{g} / \mathrm{L}$ for BPI000I.

port the general idea that enhanced recycling of NADH $[28,29]$ or NADPH $[30,31]$ in the XR-XDH pathway helps decreasing xylitol formation and can eventually increase the ethanol yield. However, two independent studies, in which exactly the same mutants of $P$. stipitis $\mathrm{XDH}$ were examined, reached opposite conclusions regarding the effect on ethanol yield resulting from the usage of $\mathrm{NADP}^{+}$ instead of $\mathrm{NAD}^{+}$in the XDH step $[30,31]$. These results emphasize the possible ambiguity in tracing back changes in strain physiology to the modification of the cosubstrate specificity of XR or XDH.

Therefore, the relevant phenotypes of the two isogenic yeast strains constructed in this work were carefully analyzed. Gene expression under control of the TDH3 promoter yielded levels of specific activity for XR (utilizing $\mathrm{NADH}$ ), $\mathrm{XDH}$, and $\mathrm{XK}$ that were about half those obtained by other groups who used the phosphoglycerate kinase 1 promoter for expressing the genes of the Pichia stipitis xylose pathway along with the endogenous XK gene $[17,55,56]$. (The comparison is relevant because purified CtXR [42] and GmXDH [57] display similar specific activities as the corresponding $P$. stipitis enzymes [44-46].) The observed ratio of the specific activities of XR-NADH, $\mathrm{XDH}$, and $\mathrm{XK}$ was $1: \approx 5-7: \approx 10$ and lies within the window of operation recommended by Hahn-Hägerdal and co-workers $[55,58]$.

We were concerned about the difference in specific XR and XK activities found in strains BP000 and BP10001 that was substantially larger than expected from the estimated experimental error of $15-20 \%$ for the entire procedure of cell disruption and activity measurement. A gene copy number effect can be ruled out considering that (1) chromosomal integration of the three overexpressed genes occurred in a single step; and (2) unlike XR and $\mathrm{XK}$, the specific activity of XDH was identical in both strains. However, for the purpose of strain comparison for xylose fermentation it may be noted that the specific uptake rates for the xylose substrate were very similar in BP000 and $\mathrm{BP} 10001$. We therefore regarded the two yeast strains as a suitable system for examining metabolic consequences resulting from the change in XR coenzyme specificity. The unknown source of variation in the specific enzyme activities was not further pursued.

The 52\% decrease in xylitol yield resulting from the genetic replacement of wild-type CtXR by the K274RN276D double mutant is quite significant in comparison to the success other metabolic engineering strategies have had in suppressing xylitol formation [for comprehensive reviews, see [1-5]], not only in terms of the magnitude of the effect but also because it was accompanied by similar changes in ethanol yield ( $42 \%$ increase) and glycerol yield ( $57 \%$ decrease). The acetate yield in bioreactor cultivations of the two strains was not affected within limits of the experimental error. Therefore, alteration of XR coenzyme specificity appears to have caused a global metabolic response, which contributes to a comprehensive improvement of the distribution of fermentation products.

It is interesting to bring into comparison these data with results of a detailed study by Jeppson et al. [56] who examined the effect of substituting wild-type XR from $P$. stipitis by a Lys ${ }^{270} \rightarrow$ Met mutant thereof, which according 
to studies of Lee and co-workers [59] exhibits a 17-fold higher $K_{\mathrm{m}}$ for NADPH than the native enzyme. The analogous site-directed replacement in CtXR, Lys $^{274} \rightarrow$ Met, caused improvement of the coenzyme selectivity, NADPH compared to NADH, from a value of 33 in the wild-type enzyme to 5.5 in the mutant [40]. However, it was also accompanied by a more substantial, 20-fold decrease in catalytic efficiency for the NADH-dependent reduction of xylose [40].

Despite the expected strong impairment of XR physiological function resulting from the mutation Lys $^{270} \rightarrow$ Met [59], the yeast strain harboring a single gene copy for $P$. stipitis mutant XR consumed xylose in batch fermentations as fast as the isogenic control strain that contained native XR, and it produced less xylitol ( 0.17 vs. $0.29 ; 42 \%$ decrease) and more ethanol ( 0.36 vs. $0.31 ; 16 \%$ increase) [56]. Formation of acetate and glycerol was, however, enhanced by about $40 \%$ in the mutant XR strain under these conditions. Interestingly, the effect of altered cosubstrate specificity of $P$. stipitis XR on ethanol yield was not clearly visible in strains that harbored two copies of the respective XR gene and hence consumed xylose about 1.5fold faster than the corresponding single-copy strains.

In a continuous culture that used a mixed sugar substrate $(10 \mathrm{~g} / \mathrm{L}$ glucose, $10 \mathrm{~g} / \mathrm{L}$ xylose $)$, the strain harboring a single gene copy for the K270M mutant produced $8 \%$ more ethanol $(0.40 \mathrm{~g} / \mathrm{g})$ and $41 \%$ less xylitol than the corresponding control strain. It was suggested from results of metabolic flux analysis that xylose conversion by the K270M mutant took place exclusively via NADH-dependent reaction while the wild-type form of $P$. stipitis XR showed balanced utilization of NADH and NADPH under these conditions (see later). Unfortunately, significant differences in physiological parameters for the native XR strains BP000 $\left(Y_{\text {EtOH } / \text { xylose }}=0.24 ; q_{\text {xylose }}=0.06 \mathrm{~h}^{-1}\right.$, where $Y$ is a yield coefficient and $q$ is the specific uptake rate) and TMB3001 $\left(Y_{\text {EtOH/xylose }}=0.31 ; q_{\text {xylose }}=0.145 \mathrm{~h}^{-1}[56]\right)$ set a limit to the quantitative evaluation of the possible benefit, particularly on $Y_{\mathrm{EtOH} / \mathrm{xylose}^{\prime}}$ originating from the use of the K274R-N276D double mutant of CtXR (this work) compared to the K270M mutant of the P. stipitis enzyme [56].

Notwithstanding, if we assume that quantitative information about XR performance under in vivo conditions can be gleaned from the results of relevant in vitro assays $[40,41]$, the CtXR double mutant is expected to be a much superior catalyst with regard to both coenzyme selectivity and efficiency. Unfortunately, the large preference for NADPH seen with isolated preparations of native P. stipitis XR $[45,46]$ is very difficult to reconcile with the suggestion from metabolic flux analysis that a very substantial fraction of xylose $(\approx 50 \%)$ is consumed by the enzyme in vivo via the NADH-dependent pathway $[56,60]$. Therefore, while further systematic integration of XR protein engineering into the development of novel xylose-fermenting strains of $S$. cerevisiae would seem to be a promising approach, it also requires that the apparent conflict in findings for in vitro and in vivo experiments be sorted out in future studies.

\section{Methods \\ Strains and plasmids}

Escherichia coli strain TOP10 (Invitrogen, Carlsbad, CA, USA) was used as bacterial host for subcloning. Saccharomyces cerevisiae strain CEN.PK 113-7D (MAT $\alpha$ MAL2-8c SUC2) was used for the isolation of yeast genomic DNA and as reference. Recombinant yeast strains were derived from uracil-deficient $S$. cerevisiae strain CEN.PK 113-5D. Plasmids pET11-CtXRWt [61] and pET11-CtXRDm [40] carry the genes encoding native and K274R-N276D double mutant forms of XR from Candida tenuis CBS4435, respectively. Plasmid pBTac1 [62] carries the gene encoding XDH from Galactocandida mastotermitis. Construction of gene cassettes for expression in S. cerevisiae was performed using plasmid pRS416GPD [63]. Yeast integrating vector YIp5 (DSMZ, Braunschweig, Germany) [40] was used for chromosomal insertion of the respective gene cassette.

\section{Media}

Bacterial transformants were selected on Luria-Bertani medium agar plates supplemented with $112 \mathrm{mg} / \mathrm{L}$ ampicillin. Prior to transformation, yeast cells were grown in YPD medium. Transformants were selected on yeast synthetic complete media agar plates prepared from Yeast Nitrogen Base (Sigma, St. Louis, MO, USA) that contained Yeast Synthetic Drop-out Medium Supplements (Sigma) lacking uracil. Xylose fermentations in shake-flask and bioreactor cultivations were performed using a defined mineral medium containing vitamins and trace elements [56]. The medium was supplemented with $0.01 \mathrm{~g} / \mathrm{L}$ ergosterol, $0.42 \mathrm{~g} / \mathrm{L}$ Tween 80 (dissolved in boiling $96 \mathrm{vol} \%$ ethanol), and $100 \mathrm{mM}$ sodium citrate buffer, $\mathrm{pH}$ 5.5.

\section{Construction of yeast integrating vectors}

Restriction enzymes were from MBI Fermentas (St. LeonRoth, Germany) or New England Biolabs (Beverly, MA, USA). Pfu DNA polymerase was from Promega (Madison, WI, USA). QIAprep Spin Miniprep Kit from Qiagen (Quiagen GmBH, Hilden, Germany) was used for plasmid preparation, and QIAquick Gel Extraction Kit was used for DNA extraction from agarose. Genomic DNA was isolated with the DNEasy Tissue Kit from Quiagen. Standard techniques of recombinant DNA technology and molecular biology were used.

In a first step, the promoterless genes for native or K274RN276D CtXR, GmXDH, and the endogenous yeast XK1 
were amplified from pET11-CtXRWt or pET11-CtXRDm, pBTac1, and genomic $S$. cerevisiae DNA, respectively. Polymerase chain reactions were performed using forward and reverse oligonucleotide primers whose 5'-ends contained a BamHI and SalI restriction site, respectively (see Table 4). Amplification products were digested with BamHI and SalI and inserted into the multiple cloning site of pRS416GPD, situated between the TDH3, formerly glyceraldehyde 3-phosphate dehydrogenase (GPD) promoter and the cytochrome-c-oxidase (CYC1) terminator. Gene cassettes were constructed where each of the target genes (XRWt, XRDm, XDH, and XK) was integrated separately between a TDH3 promoter and CYC1 terminator. Correct insertion was verified by sequencing. In a second step, the gene cassettes were amplified by PCR using oligonucleotide primers containing restriction sites at their respective 5 '-end that are unique for YIp5 (see Table 4, Figure 5). The XK gene cassette was cloned into the AatII site, resulting in vector YXKS1. Third, the XDH gene cassette was inserted into the ClaI site of YXKS1, resulting in YGmXDH/XKS1. Fourth and finally, the gene cassette for either XRWt or XRDm was cloned into the EcoRI site of $\mathrm{YGmXDH} / \mathrm{XKS} 1$, resulting in YCtXRWt/GmXDH/XKS1 and YCtXRDm/GmXDH/XKS1. Correct orientation of the inserted gene cassettes was verified after each step of integration using PCR screening with a pair of oligonucleotide primers matching a sequence upstream of the cloning site in the target vector and a sequence of the inserted gene.

\section{Transformation}

Transformation of plasmids into Top10 competent cells was done by electroporation. Yeast integrating plasmids YCtXRWt/GmXDH/XKS1 and YCtXRDm/GmXDH/XKS1 were cleaved by $S d a$ I within the URA3 gene. The linearized vectors were transformed into $S$. cerevisiae CEN.PK 113$5 \mathrm{D}$ using the lithium acetate method [64], resulting in the strains BP000 and BP10001 that express the gene encoding wild-type CtXR and the K274R-N276D double mutant thereof, respectively. Selected yeast strains were stored in $15 \%$ glycerol at $-80^{\circ} \mathrm{C}$.

\section{Fermentation of xylose under oxygen-limited culture conditions in shake flasks}

Oxygen limitation during batch conversion of xylose by BP000 and BP10001 was achieved using 300-mL baffled shake flasks that were tightly closed with rubber stoppers. Two glass tubes were inserted in the stopper, one with a valve for purging with nitrogen and another containing a narrow slit at its closed far end which served as gas outlet. A magnetic stirrer bar ( $3 \mathrm{~cm}$ in diameter) was added to each shake flask. A fluorescence-based fiber-optic sensor (PreSens GmbH, Regensburg, Germany) was used to measure the concentration of dissolved $\mathrm{O}_{2}$ in the medium each time when a sample was taken. The $\mathrm{O}_{2}$ concentration never exceeded a value of $20 \mu \mathrm{M}$.
Yeast cells were grown overnight at $30^{\circ} \mathrm{C}$ and $110 \mathrm{rpm}$ using a defined mineral medium that contained $20 \mathrm{~g} / \mathrm{L}$ glucose. They were harvested by centrifugation (10 min; $4400 \mathrm{~g}$ ) and after washing twice with $0.9 \% \mathrm{NaCl}$ used for inoculation, to give a final optical density of $\approx 4$. The working volume of each shake flask was $280 \mathrm{~mL}$, and mineral medium containing $20 \mathrm{~g} / \mathrm{L}$ xylose was used. The concentration of xylose at the start of the fermentation was increased in some cases to about $21 \mathrm{~g} / \mathrm{L}$ as result of evaporation during the sterilisation. Note that reported data is always from measurements of the actual sugar concentrations. Shake flasks were purged with $\mathrm{N}_{2}$ containing less than $5 \mathrm{ppm} \mathrm{O}_{2}$ for 15 minutes before and 5 minutes after the inoculation. Further incubation of the sealed flasks was carried out at $30^{\circ} \mathrm{C}$ and $100 \mathrm{rpm}$ using a Sartorius incubator. Care was taken that during withdrawing a sample $(\approx 3 \mathrm{~mL}$ ) from the shake flask, the biomass was homogeneously suspended. This was achieved by magnetic stirring and done under nitrogen purging. Work-up of samples and analytical procedures are described in a separate section, Analyses. Xylose fermentations were done in triplicate for each strain, and the results show mean values and the corresponding S.D. (Table 3, Figure 3)

\section{Fermentation of xylose in anaerobic bioreactor cultivations}

A Braun Biostat C bioreactor equipped with two sixbladed disc impellers was used. The bioreactor had a working volume of $4 \mathrm{~L}$. The ratio of impeller to reactor diameter was 0.4 . Fermentations were carried out under conditions exactly comparable to the ones used for shakeflask experiments. The stirrer speed was set to a constant value of $200 \mathrm{rpm}$. The reactor was sparged with $\mathrm{N}_{2}$ at a flow rate of $0.5 \mathrm{~L} / \mathrm{min}$. The $\mathrm{pH}$ was controlled at a value of 5.0 through automatic addition of $1 \mathrm{M} \mathrm{NaOH}$.

\section{Carbon balance and ethanol evaporation}

Carbon balances for xylose fermentation in shake flasks are based on the assumption that 1 mole of $\mathrm{CO}_{2}$ is formed per mole of ethanol and acetate. For carbon balances for fermentations in the bioreactor, $\mathrm{CO}_{2}$ was calculated from the off gas analysis. Due to sparging with $\mathrm{N}_{2}$, ethanol is evaporated from the bioreactor. The rate of ethanol evaporation was determined at a $\mathrm{N}_{2}$ flow rate of $0.5 \mathrm{~L} / \mathrm{min}$, measuring by HPLC the decrease in the ethanol concentration as a function of time. Mineral medium lacking biomass was supplemented with 3 concentrations of ethanol between 1 and $4.5 \mathrm{~g} / \mathrm{L}$. Time-dependent loss of ethanol from this mixture could be described by a first-order decay function with a rate constant of $4.410^{-3} \mathrm{~h}^{-1}$. Reported values for the ethanol produced include the calculated evaporated alcohol. 
Table 4: Cloning strategy for the construction of yeast integrating plasmids YCtXRWt/GmXDH/XKSI and YCtXRDm/GmXDH/XKSI. The shown primer sets were used to amplify the target sequences from the template plasmids. The amplification products were cloned into the corresponding restriction sites of the target plasmid.

\begin{tabular}{|c|c|c|c|c|c|c|}
\hline & Target sequence & Template plasmid & $\begin{array}{l}\text { Primers } \\
\text { (restriction sites underlined) }\end{array}$ & Target plasmid & Restriction sites & Resulting plasmid \\
\hline \multirow[t]{6}{*}{ । } & $C_{t} \times R W t$ gene & pETII-CtXRWt & $\begin{array}{l}\text { Fwd: } \\
\text { 5'-GGTGGTGGATCCATGAG } \\
\text { CGCAAGTATCCGAGAC-3' }\end{array}$ & pRS4I6GPD & $\begin{array}{c}\text { BamHI } \\
\text { Sall }\end{array}$ & pRS4I6GPD-CtXRWt \\
\hline & $C t$ XRDm gene & pETII-CtXRDm & $\begin{array}{l}\text { Rev: } \\
\text { 5'CTAGTGGGTCGACTTAAAC } \\
\text { GAAGATTGGAATGTTGTC-3' }\end{array}$ & pRS4I6GPD & $\begin{array}{c}\text { BamHI } \\
\text { Sall }\end{array}$ & pRS4I6GPD-CtXRDm \\
\hline & GmXDH gene & pBTacl & $\begin{array}{l}\text { Fwd: } \\
\text { 5'-GGTGGTGGATCCATGTCT } \\
\text { ACTCCTGAAAACTTATCT-3' }\end{array}$ & pRS4I6GPD & $\begin{array}{c}\text { BamHII } \\
\text { Sall }\end{array}$ & pRS4I6GPD-GmXDH \\
\hline & & & $\begin{array}{l}\text { Rev: } \\
\text { 5'-CTAGTGGGTCGACTTAC } \\
\text { TCAGGGCCGTTAATGATG-3' }\end{array}$ & & & \\
\hline & XKSI gene & Genomic S. cerevisiae DNA & $\begin{array}{l}\text { Fwd: } \\
\text { 5'-GGTGGTGGATCCATGTTG } \\
\text { TGTTCAGTAATTCAGAGA-3' }\end{array}$ & pRS4I6GPD & $\begin{array}{l}\text { BamHII } \\
\text { Sall }\end{array}$ & pRS4I6GPD-XKSI \\
\hline & & & $\begin{array}{l}\text { Rev: } \\
\text { 5'-GGTGGTGTCGACTTAGAT } \\
\text { GAGAGTCTTTTCCAGTTC-3' }\end{array}$ & & & \\
\hline \multirow[t]{2}{*}{2} & Gene cassette $^{\mathrm{a}} \mathrm{XKSI}$ & pRS4I6GPD-XKSI & $\begin{array}{l}\text { Fwd: } \\
\text { 5'-CATGGTGACGTCAGTTTATC } \\
\text { ATTATCAATACTCGCCATTTC-3' }\end{array}$ & YiP5 & Aatll & YXKSI \\
\hline & & & $\begin{array}{l}\text { Rev: } \\
\text { 5'-GGTGGTGACGTCGGCCGCA } \\
\text { AATTAAAGCCTTCG-3' }\end{array}$ & & & \\
\hline \multirow[t]{2}{*}{3} & Gene cassette $G m \times D H$ & pRS4I6GPD-GmXDH & $\begin{array}{l}\text { Fwd: } \\
\text { 5'-CATGGTATCGATAGTTTATC } \\
\text { ATTATCAATACTCGCCATTTC-3' }\end{array}$ & YXKSI & Clal & YGmXDH/XKSI \\
\hline & & & $\begin{array}{l}\text { Rev: } \\
\text { 5'-GGTGGTATCGATGGCCGCA } \\
\text { AATTAAAGCCTTCG-3' }\end{array}$ & & & \\
\hline \multirow[t]{2}{*}{4} & Gene cassette $C t X R W_{t}$ & pRS4I6GPD-CtXRWt & $\begin{array}{l}\text { Fwd: } \\
\text { 5'-GGTGGTGAATTCAGTTTATC } \\
\text { ATTATCAATACTCGCCATTTC-3' }\end{array}$ & YGmXDH/XKSI & EcoRI & $\mathrm{YCt}$ XRWt/GmXHD/XKSI \\
\hline & Gene cassette $C t \times R D m$ & pRS4I6GPD-CtXRDm & $\begin{array}{l}\text { Rev: } \\
\text { 5'-GGTGGTGAATTCGGCCGCA } \\
\text { AATTAAAGCCTTCG-3' }\end{array}$ & YGmXDH/XKSI & EcoRI & $\mathrm{YCt}$ XRDm/GmXHD/XKSI \\
\hline
\end{tabular}

a Gene cassettes contain S. cerevisiae TDH3 promoter (labeled GPD in the Table) - target gene - S. cerevisiae CYCI terminator

\section{Analyses}

Cell growth and cell dry weight

Optical density at $600 \mathrm{~nm}\left(\mathrm{OD}_{600}\right)$ was used to monitor cell growth. Cell dry weight (CDW) was determined by filtering $50 \mathrm{~mL}$ sample through a $0.45-\mu \mathrm{m}$ cellulose acetate membrane filter (Sartorius type 111, $47 \mathrm{~mm}$ diameter; Satorius, Göttingen, Germany) that had been dried $\left(110^{\circ} \mathrm{C}, 12 \mathrm{~h}\right)$ and weighed prior to use. After two washes of the filter cake with deionized water, the filter was dried overnight at $105^{\circ} \mathrm{C}$ and then weighed. The relationship between $\mathrm{OD}_{600}$ and CDW was carefully calibrated.

\section{Off gas analysis}

The concentrations of $\mathrm{CO}_{2}$ and $\mathrm{O}_{2}$ in the bioreactor off gas were measured with an IN1313 acoustic gas analyzer (Innova AirTech Instruments, Ballerup, DK) according to instructions by the instrument supplier.

\section{Extracellular products}

Samples taken from shake flasks or the bioreactor were filtered with a Satorius Minisart RC4 filter and unless used immediately, stored at $-20^{\circ} \mathrm{C}$. The product distribution resulting from xylose fermentation was analyzed by
HPLC. A Merck-Hitachi LaChrome HPLC System equipped with an Aminex HPX-87H (Biorad, Richmond, CA, USA) column, a Merck-Hitachi LaChrome L-7250 autosampler and a Merck L-7490 RI detector was used. The system was operated at $65^{\circ} \mathrm{C}$, using a flow rate of 0.6 $\mathrm{mL} / \mathrm{h}$ for the eluent ( $5 \mathrm{mM}$ sulfuric acid). Under these conditions, glucose, xylose, xylitol, glycerol, ethanol and acetate could be analyzed quantitatively.

Determination of intracellular enzyme activities

Yeast cells were grown in shake flasks under aerobic conditions at $30^{\circ} \mathrm{C}$ using a defined mineral medium that contained $20 \mathrm{~g} / \mathrm{L}$ glucose and was optionally supplemented with $20 \mathrm{~g} / \mathrm{L}$ xylose. Agitation was at $140 \mathrm{rpm}$. They were harvested in the mid-exponential growth phase using centrifugation (10 $\mathrm{min} ; 4400 \mathrm{~g}$ ). After washing twice with saline, the cell material was treated with the lysis reagent Y-PER (Pierce, Rockford, IL, USA) according to instructions of the supplier or disrupted in a French Press (SLMAminco French Press Mini Cell; 19000 psi internal cell pressure, two passages). The crude cell extract obtained by either of the two methods was used for determination of total protein, employing the Roti-Quant protein assay 
(Carl Roth GmbH, Karlsruhe, Germany) referenced against BSA fraction 5, and for enzyme activity measurements. Standard spectrophotometric assays for XR, XDH, and XK activity were described previously. Briefly, initial rates of XR-catalyzed reduction of xylose $(700 \mathrm{mM})$ were measured, unless indicated otherwise, in the presence of $350 \mu \mathrm{M}$ NADH or NADPH [40]. The XDH activity was determined using $150 \mathrm{mM}$ xylitol and $2 \mathrm{mM} \mathrm{NAD}^{+}$[65]. The continuous coupled enzymatic assay for XK activity contained $5 \mathrm{mM}$ ATP and $4.3 \mathrm{mM}$ D-xylulose [66]. Relevant controls were recorded in all cases, and reported values are corrected for the blank readings. When measuring XK activity, it was particularly important to take into account the blank resulting from the XDH-catalyzed reduction of D-xylulose by the NADH present in the assay mixture. A Beckman Coulter DU 800 UV/Vis spectrophotometer was used to monitor enzymatic rates of formation (XDH) or depletion of NADH (XR, XDH) and NADPH $(\mathrm{XR})$ at $340 \mathrm{~nm}$.

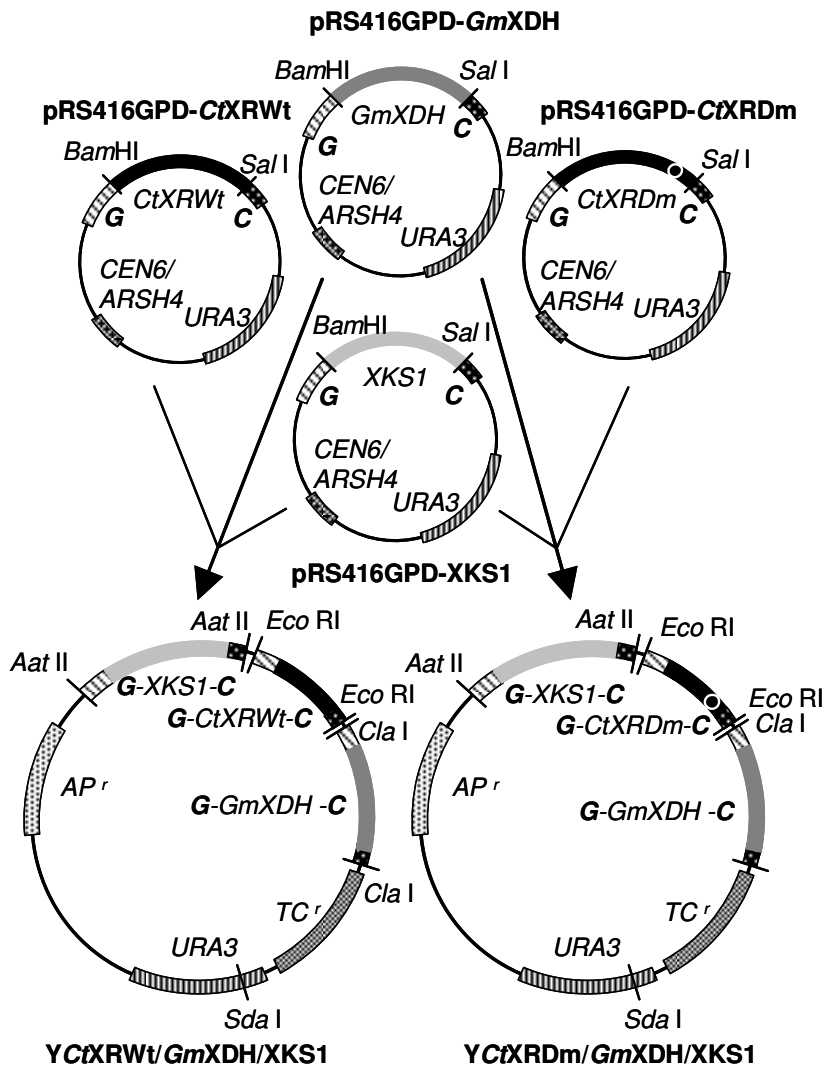

Figure 5

Cloning strategy employed for construction of plasmids YCtXRWt/GmXHD/XKSI and YCtXRWDm/ GmXHD/XKSI. Further details are given in Table 4 and text. The TDH3 promoter and the $\mathrm{CYCl}$ terminator are labeled $\mathrm{G}$ and $\mathrm{C}$, respectively.

\section{Competing interests}

The author(s) declare that they have no competing interests.

\section{Authors' contributions}

All authors have read and approved the final manuscript. $\mathrm{BP}$ and $\mathrm{BN}$ designed research; BP performed experiments and analyzed data; $\mathrm{BP}$ and $\mathrm{BN}$ wrote the paper.

\section{Acknowledgements}

Plasmid pRS4 16GPD was a kind gift of Dr. Harald Pichler (Institute of Molecular Biotechnology, Graz University of Technology). S. cerevisiae strains CEN.PK I I3-7D and CEN.PK I I3-5D were kindly provided by Dr. Jochen Förster (Fluxome Sciences A/S, Lyngby, Denmark). The authors acknowledge financial support from Vogelbusch $\mathrm{GmbH}$ and would like to thank Dr. Eva Steiner for encouragement and discussion. B.N. thanks the Austrian Science Funds (FWF project P-18275-B09) for support.

\section{References}

I. Hahn-Hägerdal B, Galbe M, Gorwa-Grauslund MF, Liden G, Zacchi G: Bio-ethanol - the fuel of tomorrow from the residues of today. Trends Biotechnol 2006, 24( I 2):549-556.

2. Otero JM, Panagiotou G, Olsson L: Fueling industrial biotechnology growth with bioethanol. Adv Biochem Eng Biotechnol 2007, I08: I-40.

3. Chu BCH, Lee H: Genetic improvement of Saccharomyces cerevisiae for xylose fermentation. Biotechnol Adv 2007 , 25(5):425-44I.

4. Hahn-Hägerdal B, Karhumaa K, Fonseca C, Spencer-Martins I, Gorwa-Grauslund MF: Towards industrial pentose-fermenting yeast strains. Appl Microbiol Biotechnol 2007, 74(5):937-953.

5. Hahn-Hägerdal B, Karhumaa K, Jeppsson M, Gorwa-Grauslund MF: Metabolic engineering for pentose utilization in Saccharomyces cerevisiae. Adv Biochem Eng Biotechnol 2007, 108:147-177.

6. Jeffries TW: Engineering yeasts for xylose metabolism. Curr Opin Biotechnol 2006, I7(3):320-326.

7. Becker J, Boles E: A modified Saccharomyces cerevisiae strain that consumes L-arabinose and produces ethanol. Appl Environ Microbiol 2003, 69(7):4|44-4I50.

8. Karhumaa K, Wiedemann B, Hahn-Hägerdal B, Boles E, GorwaGrauslund MF: Co-utilization of L-arabinose and D-xylose by laboratory and industrial Saccharomyces cerevisiae strains. Microb Cell Fact 2006, 5: 18.

9. Richard P, Verho R, Putkonen M, Londesborough J, Penttila M: Production of ethanol from L-arabinose by Saccharomyces cerevisiae containing a fungal $L$-arabinose pathway. FEMS Yeast Res 2003, 3(2): 185-189.

10. Sedlak M, Ho NW: Production of ethanol from cellulosic biomass hydrolysates using genetically engineered Saccharomyces yeast capable of cofermenting glucose and xylose. Appl Biochem Biotechnol 2004, I I 3- I | 6:403-4 I6.

II. van Maris AJ, Abbott DA, Bellissimi E, van den Brink J, Kuyper M, Luttik MA, Wisselink HW, Scheffers WA, van Dijken JP, Pronk JT: Alcoholic fermentation of carbon sources in biomass hydrolysates by Saccharomyces cerevisiae: current status. Antonie Van Leeuwenhoek 2006, 90(4):391-4I8.

12. Aristidou A, Penttilä M: Metabolic engineering applications to renewable resource utilization. Curr Opin Biotechnol 2000, II(2): I87-198

13. Koetter P, Ciriacy M: Xylose fermentation by Saccharomyces cerevisiae. Appl Microbiol Biotechnol 1993, 38:776-783.

14. Walfridsson M, Hallborn J, Penttilä M, Keranen S, Hahn-Hägerdal B: Xylose-metabolizing Saccharomyces cerevisiae strains overexpressing the TKLI and TALI genes encoding the pentose phosphate pathway enzymes transketolase and transaldolase. Appl Environ Microbiol 1995, 6 I ( I2):4I84-4190.

15. Tantirungkij M, Nakashima N, Seki T, Yoshida T: Construction of xylose-assimilating Saccharomyces cerevisiae. J Ferment Bioeng 1993, 75(2):83-88 
16. Toivari MH, Aristidou A, Ruohonen L, Penttilä M: Conversion of xylose to ethanol by recombinant Saccharomyces cerevisiae: importance of xylulokinase (XKSI) and oxygen availability. Metab Eng 200I, 3(3):236-249.

17. Eliasson A, Christensson C, Wahlbom CF, Hahn-Hägerdal B: Anaerobic xylose fermentation by recombinant Saccharomyces cerevisiae carrying $X Y L I, X Y L 2$, and XKSI in mineral medium chemostat cultures. Appl Environ Microbiol 2000, 66(8):338I-3386.

18. Ho NW, Chen Z, Brainard AP: Genetically engineered Saccharomyces yeast capable of effective cofermentation of glucose and xylose. Appl Environ Microbiol 1998, 64(5): 1852-1859.

19. Bruinenberg PM, de Bot PHM, van Dijken JP, Scheffers WA: The role of redox balances in the anaerobic fermentation of xylose by yeasts. Eur J Appl Microbiol Biotechnol 1983, 18:287-292.

20. Bruinenberg PM, de Bot PHM, van Dijken JP, Scheffers WA: NADHlinked aldose reductase: the key to anaerobic alcoholic fermentation of xylose by yeasts. Appl Microbiol Biotechnol 1984, 19:256-260.

21. van Dijken JP, Scheffers WA: Redox balances in the metabolism of sugars by yeasts. FEMS Microbiol Rev 1986, 35:199-224.

22. Wahlbom CF, Hahn-Hägerdal B: Furfural, 5-hydroxymethyl furfural, and acetoin act as external electron acceptors during anaerobic fermentation of xylose in recombinant Saccharomyces cerevisiae. Biotechnol Bioeng 2002, 78(2): I72-I 78.

23. Bro C, Regenberg B, Förster J, Nielsen J: In silico aided metabolic engineering of Saccharomyces cerevisiae for improved bioethanol production. Metab Eng 2006, 8(2): I02-III.

24. Jeppsson M, Johansson B, Hahn-Hägerdal B, Gorwa-Grauslund MF Reduced oxidative pentose phosphate pathway flux in recombinant xylose-utilizing Saccharomyces cerevisiae strains improves the ethanol yield from xylose. Appl Environ Microbiol 2002, 68(4):1604-1609.

25. Roca C, Nielsen J, Olsson L: Metabolic engineering of ammonium assimilation in xylose-fermenting Saccharomyces cerevisiae improves ethanol production. Appl Environ Microbiol 2003 , 69(8):4732-4736.

26. Sonderegger M, Schumperli M, Sauer U: Metabolic engineering of a phosphoketolase pathway for pentose catabolism in Saccharomyces cerevisiae. Appl Environ Microbiol 2004 70(5):2892-2897.

27. Verho R, Londesborough J, Penttila M, Richard P: Engineering redox cofactor regeneration for improved pentose fermentation in Saccharomyces cerevisiae. Appl Environ Microbiol 2003. 69(10):5892-5897.

28. Watanabe S, Abu Saleh A, Pack SP, Annaluru N, Kodaki T, Makino K: Ethanol production from xylose by recombinant Saccharomyces cerevisiae expressing protein-engineered NADH-preferring xylose reductase from Pichia stipitis. Microbiology 2007 , I 53 (Pt 9):3044-3054.

29. Watanabe S, Pack SP, Saleh AA, Annaluru N, Kodaki T, Makino K The positive effect of the decreased NADPH-preferring activity of xylose reductase from Pichia stipitis on ethanol production using xylose-fermenting recombinant Saccharomyces cerevisiae. Biosci Biotechnol Biochem 2007, 7 I (5): I 365- I 369.

30. Hou J, Shen Y, Li XP, Bao XM: Effect of the reversal of coenzyme specificity by expression of mutated Pichia stipitis xylitol dehydrogenase in recombinant Saccharomyces cerevisiae. Lett Appl Microbiol 2007, 45(2): I84- 189.

31. Watanabe S, Saleh AA, Pack SP, Annaluru N, Kodaki T, Makino K: Ethanol production from xylose by recombinant Saccharomyces cerevisiae expressing protein engineered NADP+. dependent xylitol dehydrogenase. J Biotechnol 2007 , 130(3):316-319.

32. Watanabe S, Kodaki T, Makino K: Complete reversal of coenzyme specificity of xylitol dehydrogenase and increase of thermostability by the introduction of structural zinc. J Biol Chem 2005, 280 (II): 10340-10349.

33. Kuyper M, Harhangi HR, Stave AK, Winkler AA, Jetten MS, de Laat WT, den Ridder J], Op den Camp HJ, van Dijken JP, Pronk JT: Highlevel functional expression of a fungal xylose isomerase: the key to efficient ethanolic fermentation of xylose by Saccharomyces cerevisiae? FEMS Yeast Res 2003, 4(I):69-78.

34. van Maris AJ, Winkler AA, Kuyper M, de Laat WT, van Dijken JP Pronk JT: Development of efficient xylose fermentation in Saccharomyces cerevisiae: xylose isomerase as a key component. Adv Biochem Eng Biotechnol 2007, 108: 179-204.
35. Walfridsson M, Bao X, Anderlund M, Lilius G, Bulow L, Hahn-Hagerdal B: Ethanolic fermentation of xylose with Saccharomyces cerevisiae harboring the Thermus thermophilus xylA gene, which expresses an active xylose (glucose) isomerase. Appl Environ Microbiol 1996, 62(I 2):4648-465I.

36. Kuyper M, Hartog MM, Toirkens MJ, Almering MJ, Winkler AA, van Dijken JP, Pronk JT: Metabolic engineering of a xylose-isomerase-expressing Saccharomyces cerevisiae strain for rapid anaerobic xylose fermentation. FEMS Yeast Res 2005, 5(45):399-409.

37. Kuyper M, Toirkens MJ, Diderich JA, Winkler AA, van Dijken JP, Pronk JT: Evolutionary engineering of mixed-sugar utilization by a xylose-fermenting Saccharomyces cerevisiae strain. FEMS Yeast Res 2005, 5(10):925-934.

38. Kuyper M, Winkler AA, van Dijken JP, Pronk JT: Minimal metabolic engineering of Saccharomyces cerevisiae for efficient anaerobic xylose fermentation: a proof of principle. FEMS Yeast Res 2004, 4(6):655-664.

39. Karhumaa K, Sanchez RG, Hahn-Hägerdal B, Gorwa-Grauslund MF: Comparison of the xylose reductase-xylitol dehydrogenase and the xylose isomerase pathways for xylose fermentation by recombinant Saccharomyces cerevisiae. Microb Cell Fact 2007, 6:5

40. Petschacher B, Leitgeb S, Kavanagh KL, Wilson DK, Nidetzky B: The coenzyme specificity of Candida tenuis xylose reductase (AKR2B5) explored by site-directed mutagenesis and X-ray crystallography. Biochem J 2005, 385(Pt I):75-83.

4I. Petschacher B, Nidetzky B: Engineering Candida tenuis xylose reductase for improved utilization of NADH: antagonistic effects of multiple side chain replacements and performance of site-directed mutants under simulated in vivo conditions. Appl Environ Microbiol 2005, 7 I ( I 0):6390-6393.

42. Neuhauser $W$, Haltrich D, Kulbe KD, Nidetzky B: NAD(P)Hdependent aldose reductase from the xylose-assimilating yeast Candida tenuis. Isolation, characterization and biochemical properties of the enzyme. Biochem J 1997, 326(Pt 3):683-692.

43. Kötter P, Amore R, Hollenberg CP, Ciriacy M: Isolation and characterization of the Pichia stipitis xylitol dehydrogenase gene, XYL2, and construction of a xylose-utilizing Saccharomyces cerevisiae transformant. Curr Genet 1990, 18(6):493-500.

44. Rizzi M, Harwart K, Erleman P, Bui-Thanh NA, Dellweg H: Purification and properties of the $\mathrm{NAD}^{+}$-dependent xylitol dehydrogenase from yeast Pichia stipitis. J Ferment Bioeng 1989, 67(2024):

45. Verduyn C, Van Kleef R, Frank J, Schreuder H, Van Dijken JP, Scheffers WA: Properties of the NAD(P)H-dependent xylose reductase from the xylose-fermenting yeast Pichia stipitis. Biochem J 1985, 226(3):669-677.

46. Rizzi M, Erleman P, Bui-Thanh NA, Dellweg H: Xylose fermentation by yeast. 4. Purification and kinetic studies of xylose reductase from Pichia stipitis. Appl Microbiol Biotechnol 1988, 29:| $148-154$

47. Metzger MH, Hollenberg CP: Amino acid substitutions in the yeast Pichia stipitis xylitol dehydrogenase coenzyme-binding domain affect the coenzyme specificity. Eur J Biochem 1995, 228(I):50-54

48. Jörnvall $\mathrm{H}$, Shafqat J, Persson B: Variations and constant patterns in eukaryotic MDR enzymes. Conclusions from novel structures and characterized genomes. Chem Biol Interact 200I, I30I 32(I-3):49|-498.

49. Persson B, Zigler JSJ, Jörnvall H: A super-family of medium-chain dehydrogenases/reductases. Sub-lines including zeta-crystallin, alcohol and polyol dehydrogenases, quinone oxidoreductases, enoyl reductases, VAT-I and other proteins. Eur $J$ Biochem 1994, 226(I): 15-22.

50. Jörnvall H, Persson B, Krook M, Atrian S, Gonzalez-Duarte R, Jeffery J, Ghosh D: Short-chain dehydrogenases/reductases (SDR). Biochemistry 1995, 34(18):6003-6013.

5I. Ehrensberger AH, Elling RA, Wilson DK: Structure-guided engineering of xylitol dehydrogenase cosubstrate specificity. Structure 2006, I4(3):567-575.

52. Kavanagh KL, Klimacek M, Nidetzky B, Wilson DK: The structure of apo and holo forms of xylose reductase, a dimeric aldoketo reductase from Candida tenuis. Biochemistry 2002, 4I(28):8785-8795. 
53. Kavanagh KL, Klimacek M, Nidetzky B, Wilson DK: Structure of xylose reductase bound to $\mathrm{NAD}^{+}$and the basis for single and dual co-substrate specificity in family 2 aldo-keto reductases. Biochem J 2003, 373(Pt 2):319-326.

54. Liang L, Zhang J, Lin Z: Altering coenzyme specificity of Pichia stipitis xylose reductase by the semi-rational approach CASTing. Microb Cell Fact 2007, 6(1):36.

55. Eliasson A, Hofmeyer JHS, Pedler S, Hahn-Hägerdal B: The xylose reductase/xylitol dehydrogenase/xylulokinase ratio affects product formation in recombinant xylose-utilising Saccharomyces cerevisiae. Enzyme Microb Technol 200I, 29:288-297.

56. Jeppsson M, Bengtsson O, Franke K, Lee H, Hahn-Hägerdal B, GorwaGrauslund MF: The expression of a Pichia stipitis xylose reductase mutant with higher $K^{M}$ for NADPH increases ethanol production from xylose in recombinant Saccharomyces cerevisiae. Biotechnol Bioeng 2006, 93(4):665-673.

57. Lunzer R, Mamnun Y, Haltrich D, Kulbe KD, Nidetzky B: Structural and functional properties of a yeast xylitol dehydrogenase, a $\mathrm{Zn}^{2+}$-containing metalloenzyme similar to medium-chain sorbitol dehydrogenases. Biochem J 1998, 336(Pt I):91-99.

58. Karhumaa K, Fromanger R, Hahn-Hägerdal B, Gorwa-Grauslund MF: High activity of xylose reductase and xylitol dehydrogenase improves xylose fermentation by recombinant Saccharomyces cerevisiae. Appl Microbiol Biotechnol 2007, 73(5): $1039-1046$.

59. Kostrzynska M, Sopher CR, Lee H: Mutational analysis of the role of the conserved lysine-270 in the Pichia stipitis xylose reductase. FEMS Microbiol Lett 1998, I59(I): 107-I I 2.

60. Wahlbom CF, Eliasson A, Hahn-Hägerdal B: Intracellular fluxes in a recombinant xylose-utilizing Saccharomyces cerevisiae cultivated anaerobically at different dilution rates and feed concentrations. Biotechnol Bioeng 200I, 72(3):289-296.

61. Hacker B, Habenicht A, Kiess M, Mattes R: Xylose utilisation: cloning and characterisation of the xylose reductase from Candida tenuis. Biol Chem I999, 380( I 2): I395- I403.

62. Habenicht A, Motejadded H, Kiess M, Wegerer A, Mattes R: Xylose utilisation: cloning and characterisation of the xylitol dehydrogenase from Galactocandida mastotermitis. Biol Chem 1999 , 380(12): I 1405-I4II.

63. Mumberg $D$, Müller R, Funk M: Yeast vectors for the controlled expression of heterologous proteins in different genetic backgrounds. Gene 1995, I56(I): I I9-122.

64. Gietz RD, Schiestl RH, Willems AR, Woods RA: Studies on the transformation of intact yeast cells by the LiAc/SS-DNA PEG procedure. Yeast 1995, I I(4):355-360.

65. Mayer G, Kulbe KD, Nidetzky B: Utilization of xylitol dehydrogenase in a combined microbial/enzymatic process for production of xylitol from D-glucose. Appl Biochem Biotechnol 2002, 98 100:577-589.

66. Di Luccio E, Petschacher B, Vögtli J, Chou HT, Stahlberg H, Nidetzky $B$, Wilson DK: Structural and kinetic studies of induced fit in xylulose kinase from Escherichia coli. J Mol Biol 2007, 365(3):783-798.

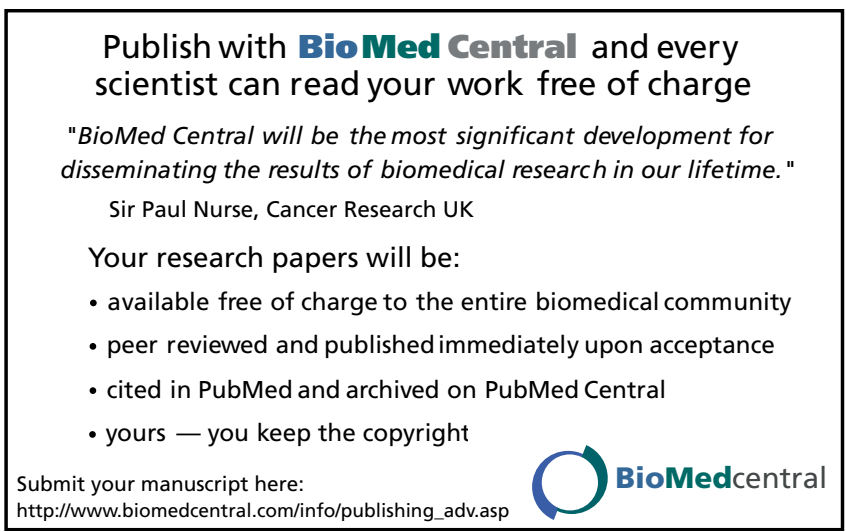

